BLACK AND GREEN 


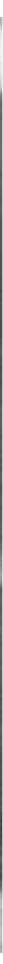




\title{
BLACK AND GREEN
}

\author{
AFRO-COLOMBIANS, DEVELOPMENT, AND \\ NATURE IN THE PACIFIC LOWLANDS \\ Kiran Asher
}

Duke University Press

Durbam and London

2009 
(C) 2009 Duke University Press

All rights reserved

Printed in the United States of America on acid-free paper $\infty$

Designed by C. H. Westmoreland

Typeset in Galliard with The Sans display by Achorn International

Library of Congress Cataloging-in-Publication Data appear on the last printed page of this book. 
TO MY MOTHER,

THE INDEFATIGABLE

VEENA VITHALDAS ASHER 
